\title{
Bioreactivity of carbon black and diesel exhaust particles to primary Clara and type II epithelial cell cultures
}

\author{
S A M Murphy, K A BéruBé, R J Richards
}

\begin{abstract}
Objectives-To begin to elucidate the mechanisms of particle toxicity to the lung, the bioreactivity of four carbon black (CB) and diesel exhaust particles ((DEPs), a surrogate for particulate matter of aerodynamic diameter $<10 \mu \mathrm{m}$ $\left(\mathbf{P} \mathbf{M}_{10}\right)$, were examined with primary cultures of Clara and type II epithelial cells. Methods-The particles were extensively characterised by surface chemistry, size, and aggregation properties. Toxicity of the particles was assessed by determining cell attachment to an extracellular matrix substratum.
\end{abstract}

Results-The spherulite size range for the particles ranged from $50,40,20,20$, and $30 \mathrm{~nm}$ for CB1-4 and DEPs. All particle samples had different surface chemical compositions. CB1 was the least toxic to Clara $(170 \mu \mathrm{g})$ and type II cells $(150 \mu \mathrm{g})$ and CB4 was the most toxic (55 $\mu \mathrm{g}$ and 23 $\mu \mathrm{g}$ respectively). DEPs stored for 2 weeks were equally toxic to both epithelial cell types $(27-28 \mu \mathrm{g})$. DEPs became progressively less toxic to type II cells with time of storage. Both primary epithelial cell types internalised the particles in culture.

Conclusions-Bioreactivity was found to be related to $C B$ particle spherulite size and hence surface area: the smaller the particle and larger the surface area, the more toxic the particles. Also, CB particles with the most complicated surface chemistry were the most bioreactive. Freshly prepared DEPs were equally toxic to type II and Clara cells and they became progressively less toxic to the type II cells with time. With all CB and DEPs, the primary epithelial cells internalised the particles, although this was noted most in cells of low functional competence.

(Occup Environ Med 1999;56:813-819)

Cardiff School of Biosciences, Cardiff University, PO Box 911, Cardiff CF1 3US, UK

S A M Murphy K A BéruBé

R J Richards

Correspondence to: Dr S A M Murphy, Cardiff School of Biosciences, Cardiff University, PO Box 911, Cardiff CF1 3US, UK.

Accepted 13 July 1999
Keywords: primary epithelial cultures; ultrafine particles; Clara cells; type II cells

Airborne particulate matter, often referred to as $\mathrm{PM}_{10}$, (particulate matter of aerodynamic diameter $<10 \mu \mathrm{m}$ ) has been linked to an increase in mortality, morbidity, and hospital attendance, particularly for those with lung or cardiovascular disorders. ${ }^{2}{ }^{2}$ However, the reasons why small increases $\left(\mu \mathrm{g} / \mathrm{m}^{3}\right)$ in particles should produce health effects or exactly how they react in the lung remain unexplained. One possibility is that many particles are ultrafine
$(<100 \mathrm{~nm})$ and if they do not aggregate they provide a large surface area for biological reaction. Such small particles may penetrate deeply into the lung and also readily translocate across the respiratory epithelium. Another suggestion is that the reactive surface properties of the particles, with a complex array of metal moieties and organic compounds, ${ }^{34}$ may produce changes in the protective lining fluids or airway surface epithelium leading to oxidative stress. $^{56}$

Within the United Kingdom, it has been estimated that $20 \%-80 \%$ of the primary $\mathrm{PM}_{10}$ emissions can be attributed to diesel exhaust particles (DEPs) and in some urban areas such as London, DEPs can account for as much as $87 \%$ of the mass of $\mathrm{PM}_{10}$ emissions. ${ }^{14}$ Deisel exhaust particles consist of individual spherical carbonaceous particles (spherulites) which readily aggregate into chains and clusters (spherules) according to their surface properties. ${ }^{78}$ Each individual particle has a turbostratic core covered by a more structured outer layer in which inorganic and organic elements may be concentrated. ${ }^{9}{ }^{10}$ Within the core there is a graphitic misfit, permitting entrapment of further inorganic elements. Thus, although DEPs may represent a simplified surrogate for United Kingdom $\mathrm{PM}_{10}$ and are more readily collected in sufficient quantities for toxicity studies, they still represent a complex physicochemical mixture. Furthermore, differences in aggregation and chemical properties may be linked to mode of collection, engine fuel type, running speed, and environmental aging of the sample. Carbon black (CB) has a similar, but somewhat simpler, graphitic structure than DEPs. ${ }^{9}$ Several forms of CB, variant in individual particle size and surface chemistry are commercially available.

In this study four samples of CB with different spherulite sizes and surface properties were examined, alongside DEPs, for their potential toxicity in a simple in vitro system with primary isolates of rodent lung epithelial cells. Previous whole animal studies have established that Clara cells of the small airways and type 2 cells of the lung parenchyma are affected by inhaled DEPs. ${ }^{11}{ }^{12}$ Thus, primary isolates of Clara cells from mice and type 2 cells from rats were chosen for the present study with particles, based on successful early differential toxicity investigations with xenobiotics. ${ }^{13} 14$ Toxicity was measured by attachment efficiency of primary cells to an extracellular matrix in the presence and absence of different doses (by mass) of CB and DEPs. The DEPs were stored for different 
Table 1 Physicochemical properties of four carbon black samples and diesel exhaust particles

\begin{tabular}{|c|c|c|c|c|c|c|c|c|}
\hline \multirow[b]{2}{*}{ Sample } & \multicolumn{5}{|c|}{ Distribution of total sample count (\%) } & \multirow[b]{2}{*}{$\begin{array}{l}S A\left(m^{2} / g\right) \text { from } \\
N_{2} \text { absorption }\end{array}$} & \multirow{2}{*}{$\begin{array}{l}\text { Mean } \\
\text { spherulite } \\
\text { diameter } \\
(\mathrm{nm})\end{array}$} & \multirow[b]{2}{*}{ Surface elemental composition } \\
\hline & $(<10 \mu \mathrm{m})$ & $(<2.5 \mu \mathrm{m})$ & $\begin{array}{l}\text { Ultrafine } \\
(<100 \mathrm{~nm})\end{array}$ & $\begin{array}{l}\text { Fine } \\
(0.1-2.5 \mu \mathrm{m})\end{array}$ & $\begin{array}{l}\text { Coarse } \\
(>2.5 \mu \mathrm{m})\end{array}$ & & & \\
\hline CB1 & 100.0 & 97.9 & 0 & 97.2 & 2.8 & 32 & 50 & $\mathrm{C}, \mathrm{O}, \mathrm{S}, \mathrm{Cl}$ \\
\hline CB2 & 98.0 & 89.6 & 0 & 82.2 & 17.8 & 62 & 40 & $\mathrm{C}, \mathrm{O}, \mathrm{S}, \mathrm{Si}, \mathrm{Fe}$ \\
\hline CB3 & 99.5 & 85.1 & 0.5 & 82.0 & 18.0 & 220 & 20 & $\mathrm{C}, \mathrm{O}, \mathrm{S}, \mathrm{Cl}, \mathrm{Si}, \mathrm{K}, \mathrm{Na}, \mathrm{Ca}$ \\
\hline CB4 & 96.9 & 72.0 & 1.0 & 65.2 & 33.8 & 230 & 20 & $\mathrm{C}, \mathrm{O}, \mathrm{S}, \mathrm{Cl}, \mathrm{Si}, \mathrm{K}$ \\
\hline DEP & 100.0 & 99.9 & 10.1 & 89.5 & 0.4 & $\mathrm{Nd}$ & 30 & $\mathrm{C}, \mathrm{O}, \mathrm{S}, \mathrm{Cl}, \mathrm{Si}, \mathrm{K}, \mathrm{Na}, \mathrm{Ca}, \mathrm{Al}, \mathrm{Fe}, \mathrm{Zn}, \mathrm{P}$ \\
\hline
\end{tabular}

${ }^{\star}$ Data supplied by Cabot Industries.

$\mathrm{SA}=$ surface area; $\mathrm{Nd}=$ not determined.
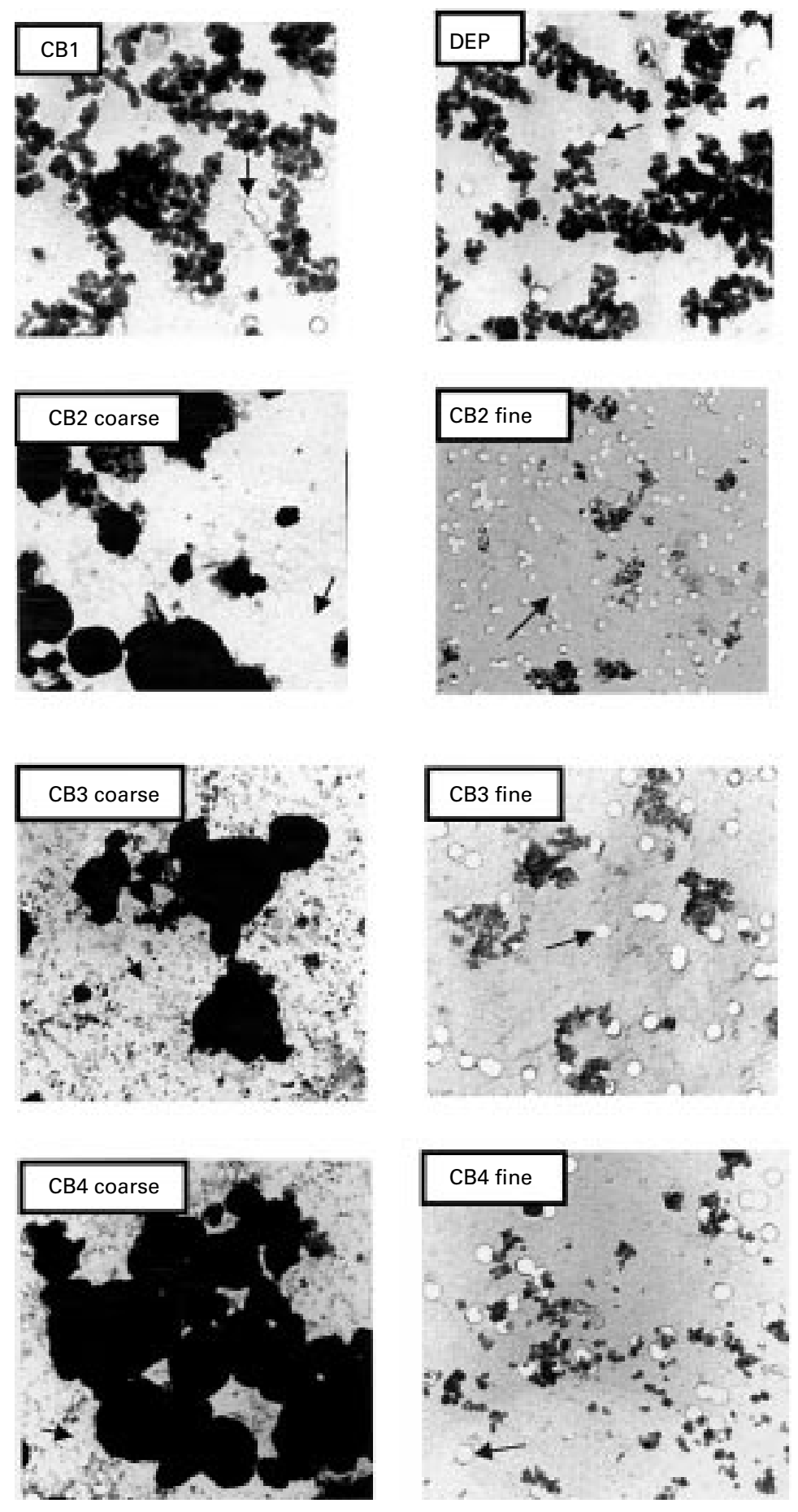

Figure 1 Transmission electron micrographs of carbon black and diesel exhaust particles to show coarse and fine fractions of $C B 2-C B 4, C B 1$, and DEPs; $C B 1$ and DEPs do not have coarse fractions. periods of up to 48 weeks after collection. Further studies with stained preparations, phase contrast, or confocal microscopy, were carried out to determine the proportion and functional status of cells carrying out endocytosis of the particles or aggregates. It was anticipated that by studying a variety of particles, clues to their mechanism of action or the importance of their size, surface area, or chemistry in toxicity reactions would emerge.

\section{Materials and methods}

MATERIALS AND ANIMALS

Synthetic, cell culture maintenance media (DCCM1), 96 well culture plates coated with extracellular matrix (ECM) and 24 well coverslips coated with ECM were obtained from Biological Industries (Beit Haemek, Israel). Ultroser G (serum substitute) and antibiotics were purchased from Gibco BRL (UK) and DNase 1 from Boehringer Mannheim (UK). Crystalline trypsin (T-8003), Percoll, and all other reagents were obtained from Sigma (UK). Male Sprague Dawley, CD rats (200$250 \mathrm{~g}$ ) and male CD mice (35-40 g) were obtained from Charles River (UK). The animals were acclimatised for 1 week in a conventional holding unit before cell isolation.

COLLECTION AND CHARACTERISATION OF PARTICLES

Diluted diesel exhaust particles (DEPs) were collected from a tractor engine exhaust burning Esso 2000 diesel fuel and 20/30 light engine oil through a total suspended particulate inlet head onto $55 \mathrm{~mm}$ Millipore DA filters as described previously. ${ }^{15}$ Discs containing DEPs were wetted by sonication in ultrapure water (Sigma, UK) and particle suspension aliquots were put onto pioloform grids coated with nickel and allowed to dry in air. Samples were examined by electron probe $x$ ray microanalysis (EPXMA) with a JEOL-JEM-1210 transmission electron microscope. The number and size of particles or their aggregates were determined by image analysis (Leica, Q500MC) and equivalent spherical diameters derived with QUIPS software. ${ }^{15}$ Carbon black samples were sonicated in ultrapure water and processed in an identical manner.

PARTICLE PREPARATION FOR ADDITION TO CELL CULTURES

A known weight of DEPs on a collection filter was wetted by immersion in DCCM1 in a wide bottomed sterile container placed in an iced sonicating water bath to disaggregate the sam- 
Table 2 Mass $(\mu \mathrm{g})$ of carbon black or DEP required to produce $T D_{50}$ values (mean (SD)) in Clara or type 2 cell cultures

\begin{tabular}{llllll}
\hline & $C B 1(n=10)$ & $C B 2(n=8)$ & $\begin{array}{l}C B 3 \\
(n=8)\end{array}$ & $C B 4(n=8)$ & $D E P$ \\
\hline Clara cells & $170(17)$ & $112(11)$ & $46(9)$ & $55(2)$ & $76(32)(\mathrm{n}=2)$ \\
Type 2 cells & $150(15)$ & $115(5)$ & $45(4)$ & $23(6)^{\star}$ & $48(20)(\mathrm{n}=15)$ \\
\hline
\end{tabular}

${ }^{\star} \mathrm{p}<0.05$ from Clara cell cultures.

$\mathrm{n}=$ Number of experiments.

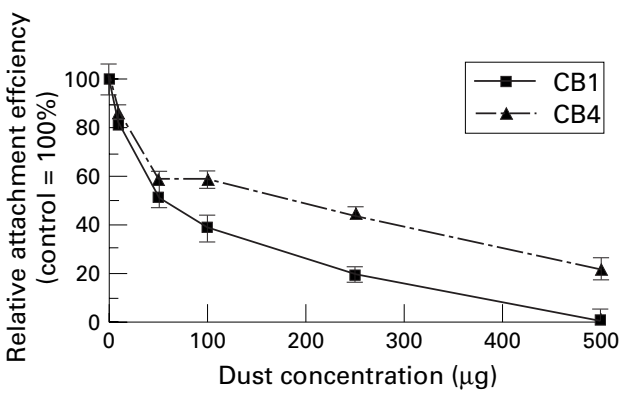

ple. An aliquot of the suspension was retained, lyophilised, reweighed, and corrected for the weight of DCCM1 for accurate determination of the DEPs removed from the filter. The suspension of particles was then diluted with further quantities of DCCM1 to produce the required concentration for addition to the culture wells. Preweighed samples of CB (CB1CB4, Cabot Corporation, Billerica, MA, USA) were similarly sonicated in DCCM1 before retaining samples for lyophilisation and preparation of a dilution series to add to the culture wells.

CELL ISOLATION AND TOXICITY ASSAYS

Primary isolates of rat type 2 cells $^{16}$ and mouse Clara cells ${ }^{17}{ }^{18}$ were prepared as reported previously. Cells purified by centrifugation and differential attachment were seeded at 100000 cells in 96 well culture plates coated with ECM that already contained dust particles $(0-500$ $\mu \mathrm{g})$. The cells were maintained in $200 \mu \mathrm{l}$ of medium (DCCM1, 2\% Ultroser G, 2\% L-glutamine, and $1 \%$ each of penicillin and streptomycin). Triplicate cultures for each dust concentration were maintained for 24 hours at $37^{\circ} \mathrm{C}$ in air: $\mathrm{CO}_{2}$ (95:5). After this time each well was washed three times with phosphate buffered saline (PBS) to remove excess particles and non-attached cells and the process checked by phase contrast microscopy. Control type 2 cell cultures at 24 hours were $>90 \%$ pure as adjudged by phase contrast microscopical observation of at least five lamellar bodies per cell. ${ }^{21}$ Clara cell cultures were $>95 \%$ pure based on cell morphology and $60 \%-70 \%$ stained strongly for NADPH dependent nitroblue tetrazolium (NBT) reductase activity, a functional marker for these cells. ${ }^{18}{ }^{21}$ Cells with strong NBT reductase activity are thought to contain high concentrations of NADPH dependent $P-450$ reductase which is vital for biotransformation. Clara cells have a much higher activity of this enzyme than type 2 cells. ${ }^{21}$ Toxicity assays were based on random counting of attached cells (300-1000/culture) after 24 hours. The number of cells attached in control cultures ( $0 \mu \mathrm{g}$ dust dose) were taken as the $100 \%$ value and those in dust treated
Figure 2 Exposure of Clara cells to different concentrations of $C B 1$ and $C B 4$ for the calculation of $T D_{50}$ values in one single experiment. (Vertical bars $=S E M$ from triplicate wells for each calculation.)

cultures expressed as a relative percentage value. The $\mathrm{TD}_{50}$ value was determined as the mass $(\mu \mathrm{g})$ of dust required for attachment of $50 \%$ of the cells found in control cultures. Statistical analysis for comparison of mean $\mathrm{TD}_{50}$ values was carried out initially with the analysis of variance (ANOVA) system, and where appropriate, (paired or unpaired) $t$ test $(\mathrm{p}<0.05)$. Further random counting of Clara cells to find the proportion with zero or weak NADPH reductase activity and the presence of intracellular particles was also undertaken by light microscopy.

\section{CONFOCAL MICROSCOPY}

Primary epithelial cell isolates were maintained and exposed to concentrations of dusts at above and below the $\mathrm{TD}_{50}$ value in 24 well plates containing an ECM coated glass insert (coverslip) for 24 hours under identical conditions as for 96 well plates. The cultures were washed with PBS solution as before and the attached cells fixed in $95 \%$ ethanol. The inserts were then removed and incubated with fluorescein isothiocyanate (FITC) conjugated Phalloidin $(2 \mu \mathrm{g} / \mathrm{ml}$, Sigma, UK) for 10 minutes. The inserts were then washed twice in PBS, mounted in Vectorshield (Vector labs, UK) and the coverslip sealed to a glass microscope slide with clear nail varnish. The sample was scanned on the confocal microscope (Sastro 2000, IRIX silicon graphics, R3000 workstation) with detectors for reflected light (to visualise particles) and fluorescence (to detect FITC-actin). Five random fields were selected for analysis and $1 \mu \mathrm{m}$ serial sections taken to examine internalised particles.

\section{Results}

PARTICLE CHARACTERISATION

Transmission electron microscope (TEM) images of the four carbon black and diluted diesel exhaust particles used in this study indicated

Table $3 T D_{50}$ values (mean (SD)) of different DEPs and storage for different periods after collection

\begin{tabular}{|c|c|c|c|c|c|c|c|}
\hline & \multicolumn{6}{|c|}{$T D_{50}$ values $(\mu g)$} & \multirow[b]{2}{*}{$\begin{array}{l}\text { All DEP } \\
(n=16)\end{array}$} \\
\hline & $\begin{array}{l}\text { DEP } 1 \\
(n=3)\end{array}$ & $\begin{array}{l}D E P 2 \\
(n=3)\end{array}$ & $\begin{array}{l}D E P 3 \\
(n=2)\end{array}$ & $\begin{array}{l}D E P 4 \\
(n=2)\end{array}$ & $\begin{array}{l}D E P 4 \\
(n=3)\end{array}$ & $\begin{array}{l}D E P 4 \\
(n=3)\end{array}$ & \\
\hline Storage time after collection (weeks) & 48 & 30 & 16 & 19 & 3 & 2 & $2-48$ \\
\hline Type 2 cells & $55(9)$ & $50(2)$ & $40(5)$ & $\star 80(9)$ & $36(5)$ & $27(3)$ & $48(20)$ \\
\hline Clara cells & $90(9)$ & $107(1)$ & $80(5)$ & $\mathrm{Nd}$ & $\mathrm{Nd}$ & $28(3)$ & $76(32)$ \\
\hline
\end{tabular}

${ }^{\star} \mathrm{p}<0.05$ From DEP 4 at 2 or 3 weeks storage.

Results from $2 / 3$ separate isolations with exposure to 5 concentrations of dust in triplicate wells.

$\mathrm{Nd}=$ Not determined; $\mathrm{n}=$ number of experiments. 

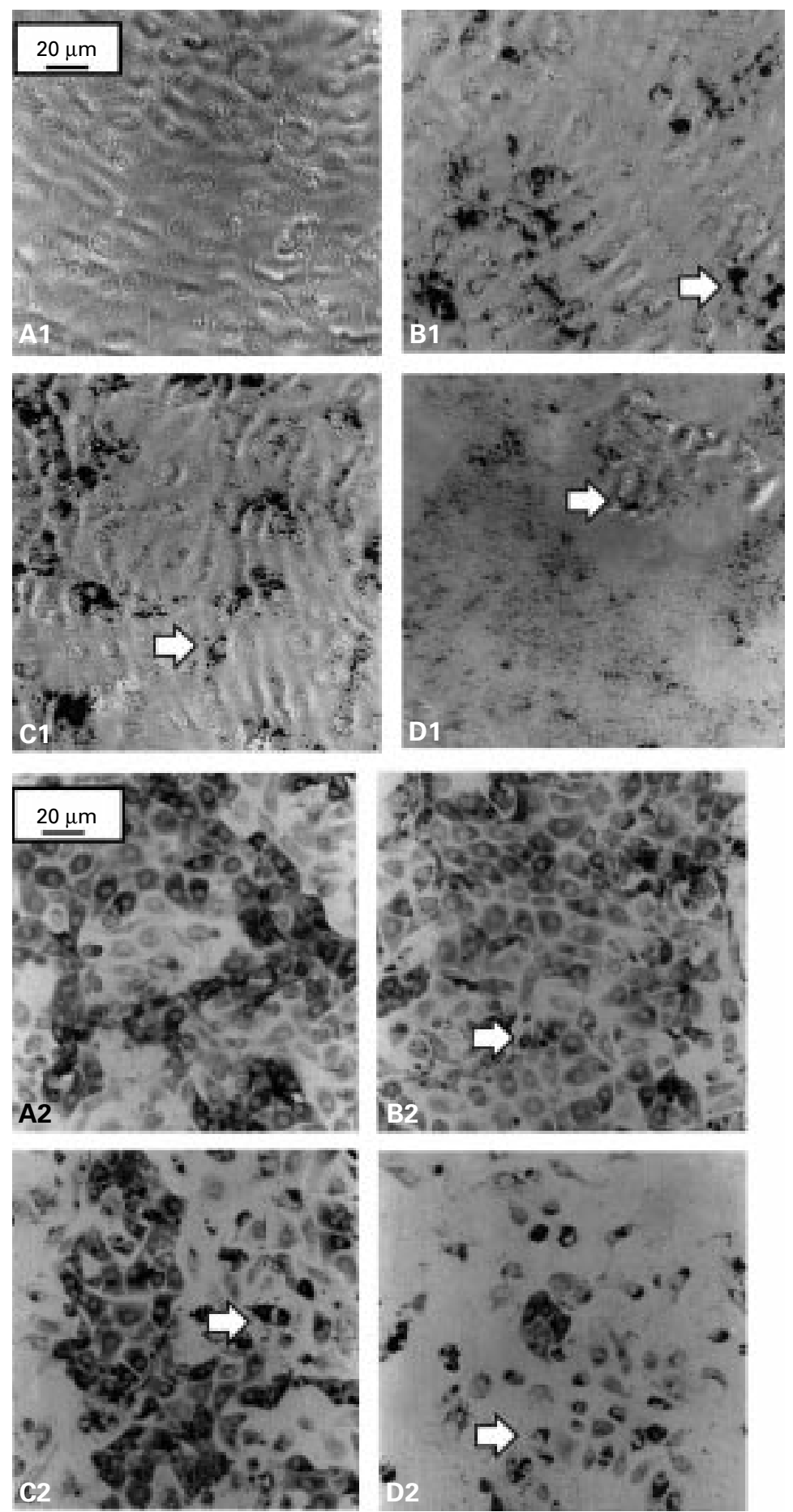

Figure 3 Light microscopy of 22 hour cultures of type II and Clara cells exposed to CB1. $A 1-D 1$ are type II cells, phase contrast microscopy. A2-D2 are Clara cells, stained for NADPH dependent nitro blue tetrazolium reductase. $A 1$ and 2 are control cultures for the repective cell types. $B 1=75 \mu \mathrm{g}, C 1=100 \mu \mathrm{g}, D 1=200 \mu \mathrm{g}, B 2=100 \mu \mathrm{g}, C 2=150 \mu \mathrm{g}, D 2=200$ $\mu g$ dust. Dust concentrations shown for the two cell types reflect the differential $T D_{50}$ values obtained. $\rightarrow$ Denotes cells packed with particles.

that all samples had a similar morphology and could form aggregations from the primary spherulites (individual particles, fig 1). The spherulites varied in mean diameter from 50 , 40, 20, 20, and $30 \mathrm{~nm}$ for CB 1-4 and DEPs, respectively (table 1). A combination of TEM and image analysis provided information on the number of clusters or aggregates of particles present in different size categories based on equivalent surface diameters. This indicated that most particles for all the samples could be classified as having a size $<10 \mu \mathrm{m}$, but that there were proportionately less respirable particles $(<2.5 \mu \mathrm{m})$ from $\mathrm{CB} 1-\mathrm{CB} 4$, respectively (table 1). Further breakdown into ultrafine $(<100 \mathrm{~nm})$, fine $(0.1-2.5 \mu \mathrm{m})$ and coarse $(>2.5 \mu \mathrm{m})$ categories showed that most particles in all the samples were fine. However, both CB3 and CB4 had higher ultrafine and coarse components than $\mathrm{CB} 1$ and $\mathrm{CB} 2$. The small ultrafine component may have a substantial influence on the surface area reported from nitrogen absorption (data supplied by Cabot Industries), which was especially high in CB3 and CB4. The surface area of the DEPs is unknown but may be greater than any of the carbon black samples because $10 \%$ by number of the DEPs were ultrafine and only a small proportion $(0.4 \%)$ were coarse. Electron probe $x$ ray microanalysis (EPXMA) for surface elements present on the particles indicated that slight, but subtle, differences existed between all the samples. The least complicated surface chemistry was found with $\mathrm{CB} 1$, a transition metal (iron) was detected on CB2 and DEPs showed a more complex array of elements than $\mathrm{CB} 3$ or CB4.

TOXICITY STUDIES WITH EPITHELIAL CELLS

The results from a single toxicity experiment exposing Clara cells to five different concentrations of each of CB1 and CB4 are shown in figure 2. From this type of experiment the $\mathrm{TD}_{50}$ value for CB1 $(150 \mu \mathrm{g})$ was about three times higher than that for CB4 $(50 \mu \mathrm{g})$. This experiment was repeated on several occasions with primary isolates of both Clara and type 2 cells for which the collective data are shown in table 2 . Both cell types responded to the different dusts in a similar manner with the exception of a significant difference between cell types for CB4. CB1 showed the lowest toxicity with CB3/4 having the highest reactivity and CB2 was intermediate in effect. The $\mathrm{TD}_{50}$ values derived collectively from DEPs indicated that it had an intermediate toxicity between CB3 or CB4 and CB2 but with a much larger standard deviation from the mean value. The toxicity of the individual samples of DEPs ${ }^{1-4}$ together with details of their storage times before use is shown in table 3. In general, samples of DEPs became less toxic after prolonged storage. For one sample of DEPs (DEPs 4), the particles proved significantly less toxic after 19 weeks storage than after 2 or 3 weeks (table 3 ). The freshest DEP sample (2 weeks storage) had a similar $\mathrm{TD}_{50}$ value for type 2 cells to that found with CB4.

INTERNALISATION OF PARTICLES

Light micrographs of type 2 cells (phase contrast) and Clara cells (stained for NADPH reductase) exposed to different concentrations of CB1 are shown in figure 3. Exhaustive washing of the cultures removed free particles leaving those that were strongly attached or internalised by the cells. At the level of light microscopy many type 2 cells seemed devoid of particles whereas others seemed to be packed with CB1 encircling the nuclear area. With 


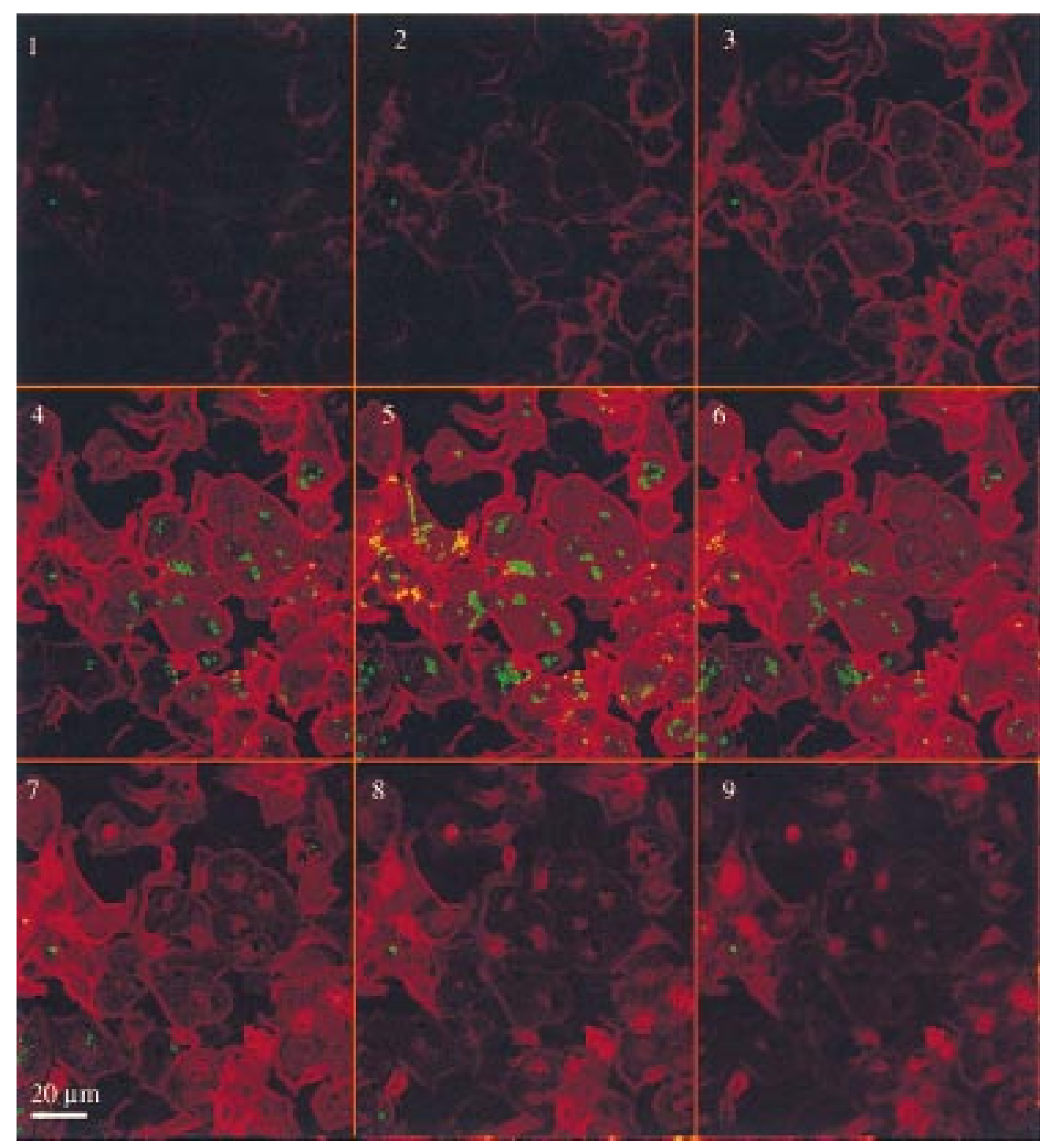

Figure 4 Confocal microscopy showing 1 m series section through Clara cells in 22 hour culture with CB1 (50 $\mu \mathrm{g})$. Red=phalloidin-FITC; green=particle reflected light.

Clara cells, a similar observation was made and from micrographs it seemed that the cells most likely to contain particles were those with low or zero staining reaction for NADPH reductase activity. Further confirmation that particles had been taken in by Clara cells (and type 2 cell cultures, data not shown) was obtained with confocal microscopy (fig 4). From serial sections with dual monitoring for reflected light and fluorescent detection of FITC Phalloidin (to visualise actin) a composite micrograph was obtained to show the presence of intracellular CB1 particles. With this method it was also shown that Clara cells of low NADPH dependent reductase activity contained many more particles. A semiquantitative evaluation by light microscope was therefore carried out on Clara cell cultures treated with $\mathrm{CB} 1$ and $\mathrm{CB} 4$ to find the proportion of cells with zero or weak NADPH reductase activity and the number containing particles (fig 5). For CB1, the proportion of cells containing particles showed a close correlation with those that had little or no reductase activity. The CB4, which is more toxic than
$\mathrm{CB} 1$, had a similar relation for dust concentrations of $\leqslant 100 \mu \mathrm{g}$. At the highest CB4 dose (250 $\mu \mathrm{g})$, when all the surviving Clara cells had lost functional reductase activity, then some $80 \%$ of these cells retained intracellular particles.

\section{Discussion}

The biological reactivity of different samples of carbonaceous particles was compared with a simple in vitro system with primary lung epithelial cells. Differential toxicity was noted with CB samples and the results were reproducible with several primary isolates. The lowest biological reactivity in vitro was found with CB1 and the same sample produced no inflammation or lung permeability when instilled into rats in small doses. ${ }^{15}$ Toxicity, in vitro, based on $\mathrm{TD}_{50}$ values, decreased proportionately with increased mean spherulite diameter. This suggests that the smaller the size of the individual particle, the greater the toxicity. However, spherulites or individual particles are rare in aqueous suspension but exist as aggregates. Each of the carbonaceous aggregates used has a slightly 

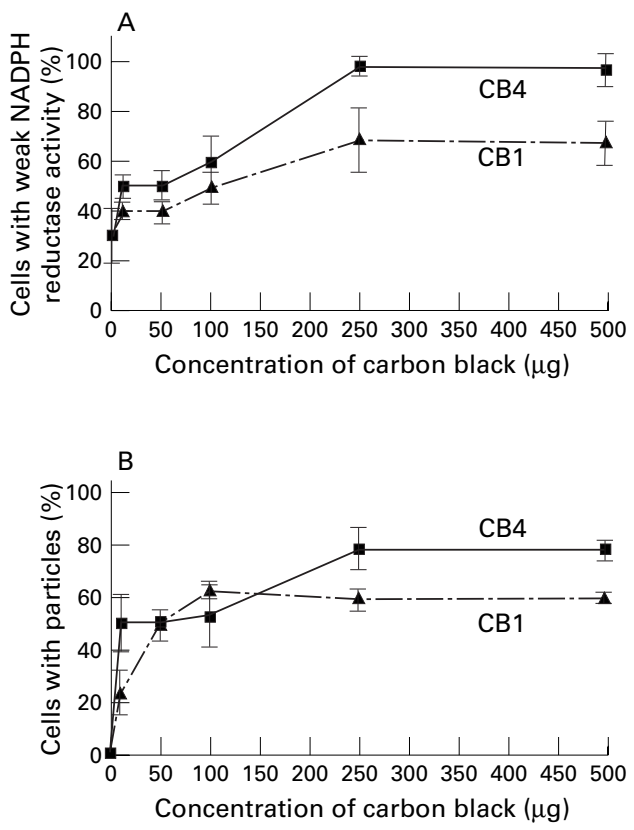

Figure 5 The proportion of cells in primary culture of Clara cells which have $(A)$ weak NADPH reductase activity, and (B) contain particles after treatment with different concentrations of $C B 1$ and $C B 4$. The vertical bars represent the SEM, $n=3$.

different size distribution and paradoxically there is an inverse relation between toxicity and the proportion of particle aggregates classified as fine. The CB3 and CB4 samples are the most reactive and have a small ultrafine component that would make a minimal contribution to mass and a coarse component making a large contribution to mass. Ultrafine particles would have a greater surface area per given mass than fine or coarse particles and indeed, surface area, calculated by nitrogen absorption, indicates a close relation to $\mathrm{CB}$ $\mathrm{TD}_{50}$ values. The smaller the surface area of the $\mathrm{CB}$ the lower the $\mathrm{TD}_{50}$ value obtained.

Although size and surface are important features to explain differential CB toxicity, each of the samples examined also has a different surface chemistry. Thus, CB1 may be the least toxic because it has a relatively pure carbonaceous surface, CB2 may be more reactive because iron is present, and CB3 and CB4 more reactive again based on the presence of additional metal contaminents. In type 2 cell cultures CB3 and CB4 have similar toxicity as DEPs which have been stored for 2-3 weeks after collection although the ultrafine component of DEPs is 10-20 times greater than the carbon black samples. This suggests, by deduction, that DEPs, which contain a minute coarse fraction, would have a much greater surface area than CB4 and yet it is equally toxic to CB4. This may suggest that size and surface area are slightly less important to explain toxicity in vitro compared with the surface chemistry, which for DEPs is quite complex.

Reproducible $\mathrm{TD}_{50}$ values can be obtained with different primary isolates and CB samples. These are more difficult to obtain with DEPs where greater masses are required to produce equivalent toxicity after prolonged storage. It seems unlikely that size distributions or surface area of DEPs would change upon storage. However, some change in surface reactivity, perhaps particularly in adsorbed organic compounds, may be anticipated upon storage of DEPs. By contrast, CB may be devoid of or have less adsorbed organic compounds. These speculations require more detailed analysis of both inorganic and organic surface components of stored CB and DEPs, which have not been undertaken in this study.

It is not known whether any of the carbonaceous particles used in this study prevent cell attachment by damaging plasma membranes or after endocytosis of the particles. Both phase contrast and confocal microscopy were used to detect aggregates of CB and DEPs being taken into both Clara and type 2 cells. There are no reports of endocytosis by Clara cells in vivo but alveolar epithelial cells have been reported to ingest asbestos fibres, ${ }^{19}$ cationic ferritin, and small amounts of dextran, ${ }^{20}$ but not colloidal carbon ( $25 \mathrm{~nm}$ particles), polystyrene beads (1 $\mu \mathrm{m})$, or iron oxide $(1 \mu \mathrm{m}) .{ }^{20}$ In the present in vitro study, CB and DEPs are internalised by both epithelial cell types and in vivo uptake has been reported in bronchial epithelial cell populations after DEP inhalation studies. ${ }^{11}$ In vitro, where overload masses of particles are reacted with small numbers of cells the endocytotic process may be easily observed whereas cellular ingestion in vivo of small instilled masse ${ }^{15}$ may be more difficult to detect from electron microscopical analysis.

Some $50 \%$ of Clara cells contained particles and these cells had low NADPH dependent reductase activity, indicating that they have a compromised biotransformation potential. Increasing concentrations of CB4 particles reduced reductase activity in Clara cells and this again was associated with increase in particle uptake. It may be surmised that older or more differentiated cells, lacking functional activity, are more susceptible to ingesting particles. Alternatively, the particles themselves may reduce reductase activity.

In conclusion, respirable $\mathrm{CB}$ samples of varying physicochemical properties and DEPs, stored for different times after collection, show differential toxicity to primary lung epithelial cells. The particles are internalised by the cells in vitro and possibly preferentially by those of low functional activity. Individual particle size, available surface area, aggregation properties, and surface chemistry are all important in the observed toxicity but the predominent characteristics still require elucidation. In view of the variation in response to $\mathrm{CB}$ and DEPs stored for different times after collection it is recommended that particles for experimental studies should be well characterised before use.

We are grateful to the Medical Research Council, UK for financing this study.

1 Department of the Environment Expert Panel on Air Quality Standards. Particles. London: The Stationery Office, 1995.

2 Urban air quality in the United Kingdom: first report of the Quality of Urban Air Review Group. Bradford: Department of the Environment, 1993.

3 Hammer M. Fighting for air. New Scientist 1997;2078: 14-15. 
4 Department of Health Committee on the Medical Effects of Air Pollution. Non-biological particles and health. London: Air Pollution. Non-biological

5 Stohs SJ, Bagchi D. Oxidative mechanisms in the toxicity of metal ions. Free Radical Biol Med 1995;18:321-36.

6 Ghio AJ, Richards JH, Dittrich KL, et al. Metal storage and transport proteins increase after exposure of the rat lung to an air pollution particle. Toxicol Pathol 1998;26:388-94

7 Lahaye J, Ehrburger-Dolle F. Mechanisms of carbon black formation: correlation with the morphology of aggregates. Carbon 1994;32:1319-24.

8 BéruBé KA, Jones TP, Williamson BJ, et al. Physicochemical characterisation of diesel exhaust particles: factors for assessing biological activity. Atmosphere and the Environment 1999;33:1599-614

9 Ishiguro T, Takatori Y, Akihama K. Microstructure of diesel soot particles probed by electron microscopy: first observa-
tion of inner core and outer shell. Combustion and Flame 1997; 108:231-4.

10 Health Effects Institute. Diesel exhaust: a critical analysis of emissions, exposure, and health effects. Cambridge, MA, USA: HEI, 1995.

11 Hyde DM, Plopper GG, Weir AJ, et al. Peribronchiolar fibrosis in lungs of cats chronically exposed to diesel exhaust. Lab Invest 1985;52:195-206.

12 Mauderly JL, Snipes MB, Barr EB, et al. Pulmonary toxicity of inhaled diesel exhaust and carbon black in chronically exposed rats. Part I, Neoplastic and non-neoplastic lung lesions. Cambridge, MA, USA: Health Effects Institute, 1994 (Research report 68.)
13 Jones HE, Blundell GK, Wyatt I, et al. The accumulation of pentamidine into rat lung slices and its interaction with putrescine. Biochem Pharmacol 1992;43:431-7.

14 Richards RJ, Oreffo VIC, Lewis RW. Clara cell cultures from the mouse and their reaction to bronchiolar toxins. Environ Health Perspect 1990;85:119-27.

15 Murphy SAM, BéruBé KA, Pooley FD, et al. The response of lung epithelium to well characterised fine particles. Life Sci 1998;62:1789-99.

16 Richards RJ, Davies N, Atkins J, et al. Isolation, biochemical characterisation and culture of lung type II cells of the rat. Lung 1987;165:143-58.

17 Oreffo VIC, Morgan A, Richards RJ. Isolation of Clara cells from the mouse lung. Environ Health Perspect 1990;85:5164.

18 Masek 1, Richards RJ. Interactions between paraquat, endogenous lung amines' antioxidants and isolated mouse Clara cells. Toxicology 1990;63:315-26.

19 Suzuki Y, Churg J, Ono T. Phagocytic activity of the alveolar epithelial cells in pulmonary asbestosis. Am f Pathol 1972; 69:373-9.

20 Williams MC. Endocytosis in alveolar type ii cells: effect of charge and size of tracers. Proc Natl Acad Sci 1984;81: 6054-8.

21 Murphy SA, Dinsdale D, Hoet P, et al. A comparative study of the isolation of type II epithelial cells from rat, hamster, pig, and human lung tissue. Methods in Cell Science 1999;20:31-8

\section{Vancouver style}

All manuscripts submitted to Occup Environ Med should conform to the uniform requirements for manuscripts submitted to biomedical journals (known as the Vancouver style.)

Occup Environ Med, together with many other international biomedical journals, has agreed to accept articles prepared in accordance with the Vancouver style. The style (described in full in the $f A M A[1]$ ) is intended to standardise requirements for authors, and is the same as in this issue.

References should be numbered consecutively in the order in which they are first mentioned in the text by Arabic numerals on the line in square brackets on each occasion the reference is cited (Manson[1] confirmed other reports[2][3][4][5]). In future references to papers submitted to Occup Environ Med should include: the names of all authors if there are three or less or, if there are more, the first three followed by et al; the title of journal articles or book chapters; the titles of journals abbreviated according to the style of Index Medicus; and the first and final page numbers of the article or chapter. Titles not in Index Medicus should be given in full.

Examples of common forms of references are:

1 International Committee of Medical Journal Editors. Uniform requirements for manuscripts submitted to biomed journals. FAMA 1993;269:2282-6.

2 Soter NA, Wasserman SI, Austen KF. Cold urticaria: release into the circulation of histmaine and eosinophil chemotactic factor of anaphylaxis during cold challenge. $\mathrm{N}$ Engl f Med 1976;294:687-90.

3 Weinstein L, Swartz MN. Pathogenic properties of invading micro-organisms. In: Sodeman WA Jr, Sodeman WA, ing micro-organisms. In: Sodeman WA Jr, Sodeman WA, phia: W B Saunders, 1974:457-72. 